\title{
SEMNIFICAȚIA DORULUI ÎN LIRICA POPULARĂ
}

\author{
Tatiana BUTNARU \\ Institutul de Filologie Română „Bogdan P.-Hasdeu” \\ ORCID: https://orcid.org/0000-0001-5771-9081
}

\begin{abstract}
Rezumat: În articolul de față este propusă spre analiză una din imaginile-cheie ale artei noastre tradiționale, metafora dorului, care determină substanța lirică a mai multor scrieri folclorice, generalizează universul trăirilor populare. Odată ce dorul definește „stări sufletești românești”, el aprofundează o complexitate de sentimente, resorturi interioare, fiind înțeles până la unele generalizări estetice ale realității, are semnificația de sintetizare a dimensiunilor ontologice a vieții omenești. Dorul tinde spre zona unei generalități absolute înfățișate prin proporțiile pe care le cunoaște sentimental trăit. Prin imaginea dorului se are in vedere caracterul perpetuu al vieții, mișcării, evoluției, vedem o codificare a sufletului românesc, ideea fundamentală a unui concept de existență viabil. În lirica populară, dorul devine o categorie estetică, el definește cel mai veritabil testament modern al spiritului național, este una din cele mai fine cristalizări ale sufletului popular, „constanta fundamentală a viziunii sale asupra lumii și vieții” (M. Bucur). Poetizarea dorului întrevede un criteriu de evaluare estetică,de promovare a valorilor general-umane, a unor atitudini preluate din experiența poporului,din tezaurul bogăției sale spirituale.

Cuvinte-cheie: geniul popular, resorturi existențiale, stare de dor, matrice stilistică, revelații interioare, revelație interioară, tezaur folcloric.
\end{abstract}

Abstract: In this article, one of the key images of our traditional art is being proposed to analyze, the metaphor of "dor", which determines the lyrical substance of several folk writings, generalizing the universe of popular feelings. Once "dor" defines the "Romanian states of mind", it deepens a complexity of feelings, inner resorts, being understood to some aesthetic generalizations of reality, these are the significance of synthesizing the ontological dimensions of human lives. The "dor" tends to an area of absolute generality represented by proportions that it knows them sentimentally lived. Through the image of the "dor" is considered the perpetual character of life, movement, evolution, we see a codification of the Romanian soul, the fundamental idea of a viable concept of existence. In folk's lyric, the "dor" becomes an aesthetic category, it defines the most genuine modern testament of the national spirit, it is one of the finest crystallizations of the popular soul, "the fundamental constant of his vision of the world and life" (M. Bucur).The poetization of the "dor" foresees a criterion of aesthetic evaluation, of promoting the general-human values, of some attitudes taken from the experience of the people, from the treasure of its spiritual richness.

Keywords: folk genius, existential resorts, state of "dor", stylistic matrix, inner revelations, inner revelation, folk treasure.

Un element indispensabil prezent în doine, precum și în alte grupuri tematice ale cântecului liric popular constituie metafora dorului, una din imaginile - cheie ale artei noastre tradiționale. Odată ce dorul definește „stări sufletești românești” [1, p. 222], el dezvăluie o complexitate de trăiri, sentimente, resor- 
turi interioare, fiind înțeles până la unele generalizări estetice ale realității, are semnificația de exteriorizare a unor aspecte ontologice a existenței omenești. Dorul tinde spre zona unei generalități absolute înfățișată prin proporțiile, pe care le cunoaște sentimentul trăit. Prin imaginea dorului se are în vedere caracterul perpetuu al vieții, al mișcării, evoluției, vedem o codificare a sufletului românesc, ideea fundamentală a unui concept de existență. În lirica populară, dorul devine o categorie estetică existențială, el definește cel mai „veritabil testament modern” [2, p. 166], este „una din cele mai fine cristalizări ale spiritului popular, constanta fundamentală a viziunii asupra lumii și vieții” [3, p.150]. Poetizarea dorului întrevede un criteriu de evaluare estetică, de promovare a unor valori și atitudini preluate din experiența poporului, din tezaurul bogăției sale spirituale și, după cum sublinia Ion Coteanu, atunci când se referea la vibrațiile sufletești ale rapsodului anonim, românul „și-a asemănat dorul cu florile, pădurile, holdele, snopii de grâu, cu luna, pâraiele, izvoarele, albinele”, precum și ” diverse obiecte simbolice” [4, p. 169].

Din lectura mai multor texte de doine, sesizăm ideea că înțelesul particular al dorului este extins până la unele generalizări artistice ale realității, este ” dorul de lumea toată," iar acesta exprimă un crez filosofic rostit cu demnitate şi convingere, încadrat în modulațiile codului estetic al poporului. Or, fiind receptată drept o „enciclopedie poetică nescrisă a poporului,” doina populară se manifestă prin niște trăsături tipologice individualizate, constituie o oglindă a vieții spirituale de epocă, este expresia trăirilor, aspirațiilor, frământărilor omenești, având drept resort de bază umanismul, promovarea principiilor estetice ale spiritualității autohtone. Prin aprofundarea „stării de dor”, autorul anonim ajunge la niște acorduri lirice copleșitoare,

"Cine zâce doina, doina

Să-i șie sfântă gura" [5, p. 241].

se spune într-o versiune de cântec popular cu vădite nuanțe lirice. Se are în vedere, un bilanț al sensibilității populare, care amplifică de pe poziția unor noi criterii valorice căutările de fond și formă transfigurate simultan prin elemente de viziune, are loc lărgirea orizonturilor din sfera inspirației general - populare, unde categoria estetică a dorului are deschidere spre contemplarea unor stări sufletești diverse. „Doina - doinelor” devine astfel o imagine de o semnificație generalizatoare, privită fiind în corelație cu dorul, ea constituie o expresie metaforică a sufletului românesc.

Și asta-i doina doinelor,

Doine de drag și de dor, 
Doine din bătrâni lăsate,

Hai, doine și iar doine. (6, p. 84)

\section{(Gheorghe Turda, Asta-i doina doinelor)}

Văzut stilistic, motivul dorului prefigurat în scrierile noastre populare, exprimă o stare plenipotențiară, care însuflețește virtuțile creatoare ale omului, îi inspiră optimism și sete de viaţă, confirmă tendința lui nemijlocită de a se desăvârși prin dragoste și crezământ. „Doina Prutului” este „ lacrima românului” și are legătură cu mioritizarea dorului de țară, de plaiul natal. În asemenea circumstanțe, „doina dorului,”o metaforă folclorică de profunzime, vibrează „cât îi lunca Nistrului” (7, p. 176), având deschidere spre o dimensiune absolută. De multe ori, neliniștea lăuntrică a geniului anonim survine din drama înstrăinării, redată metaforic printr-o serie de imagini și sugestii poetice oximoronice, care în contextul semnalat mai exprimă nealterarea ideii de țară și neam, este răvășirea dramatizată a unui cosmos marcat de dramele timpului istoric, ce și-au găsit expresie atât de pregnant în lirica populară.

Prutule întunecat,

Mal cu plâns amestecat,

Tu desparți ca un dușman

Moldovan de moldovan.

Of, Prutule.

Peste Țara cea Ștefană

Tu desparți de la Carpați

Până-n vale la Galați

Grai de grai de la o mamă

Și la nimeni nu dai seamă. $(6$, p. 95)

Nostalgia sacrului revendică dorința de revigorare, de revenire la, matricea stilistică ” originară, în, „Țara cea Ștefană." E „dorul permanent după locul nostru unic în univers" (2, p. 136), o latură componentă a sufletului popular și,în același timp,o parte integrantă a ființei lui colective. $\mathrm{Cu}$ alte cuvinte, dorul de plai intră în cadrul unei anumite individualizări artistice,pe care poetul anonim îl redă printr-o vibrație lirică copleșitoare. Melodicitatea versului,claritatea,profunzimea exprimării determină orizonturile simțirii populare.

Și mai lin, dorule lin,

Că pe iei e loc strain,

Și mai rar, dorule, rar,

Că pe ici e loc amar. (8, p.106) 
De aici survin și niște incursiuni poetice despre îndeletnicirile zilnice ale oamenilor, pe care folcloristul T. Colac, le mai numește și „cântece plugărești” (9, p. 7), apreciate în același timp, drept cântece despre drag și iubire.Prezentăm un exemplu:

Frunză verde bob ormug,

Și-am plecat cu cucu-n plug-

El să cânte, eu să mân;

Dorul să ție de coarne,

Dragostea să puie boabe,

Mândra, albă ca o floare,

Să ne-a ducă de mâncare. $(8$, p. 258)

Dorul se contopește cu lumina lăuntrică a unui suflet îndrăgostit de viață, dezvăluie o gamă complexă de revelații interioare, care generalizează universul sensibilității populare,iar prin culminația emoțională exprimată, autorul anonim atinge dimensiunile baladescului.

Colo-n vârful codrului

Cântă puiul cucului,

Cântă dorul dorului,

A-u-u-u-u, a-u-u-u-u, au (6, p. 100)

Dorul de codrul verde se manifestă prin tendința nemijlocită de a doini la nesfârșit, a-și confirma existența, chezășia, vitalitatea, a venera strămoșii, a iubi oamenii și meleagul natal. Este o vibrație continuă a sufletului izvorâtă din deplina îngemănare cu frumusețea strădaniei umane, a unei etnii multiseculare zămislite în dorul de părinți, de frați și de surori, dorul de semenii noștri,oamenii dragi din preajmă, așa cum ne sugerează versurile ce urmează în continuare:

Jelui-m-aș brazilor

De dorul fraților;

Jelui-m-aș munților

De dorul părinților;

Jelui-m-aș florilor

De dorul surorilor. (10, p. 16-17)

Culminația emoțională a dorului constă în neobișnuita lui capacitate de germinație,în posibilitatea de a însufleți cosmosul terestru,dar și pentru a exprima setea de absolut,de adâncimi stelare.

„Pe unde trece dorul/ Crește iarba și locul," spune rapsodul popular. Este vorba de o existență unde absolut totul din jur poate fi perceput și 
interpretat drept o jubilație a dorului, a împlinirii lăuntrice, o celebrare a rodirii și înfloririi. De atâta dor și efervescență sufletească,de atâta drag de lume „a crescut un pom pe coastă”, imagine care la rândul ei vine „încărcată” cu sensuri adânci și sugestive. Raportată direct la ființa omenească,valoarea artistică a metaforei constă în idea de împlinire. Este acea categorie estetică a „preaplinului emoțional” (11, p. 3),care are deschidere spre un complex de valori autohtone, trezește la viață,îndeamnă să înverzească pomul și iarba, să răsară dragostea.

Pomu-i mare, frunza-i rară,

Pasările prin ea zboară

Și zboară din pom în pom,

Ca dorul din om în om. (12, p. 68)

Iar „dorul din om în om ” capătă o semnificație estetică aparte și, în același timp, o nuanță de adâncime mitică, relevă comuniunea sufletească cu aproapele din preajmă, exprimă legătura cu tot neamul adunat „grămăjoară”,vorba lui Gr. Vieru, într-o „singură icoană.”

Ca putere impersonală și „element invincibil al firii” (1, p. 85), ca o „emanație materială - sufletească a individului” (1, p. 85), așa cum definește dorul L. Blaga, el se fundamentează în baza unor legităţi specifice ale creativității populare, manifestate în interferențe și suprapuneri de sensuri. Cercetătorul M. Drăgan depistează următoarele cupluri corelative, unde figurează metafora dorului: , dor-vis, dor-gând, dor - cântec, dor - patimă, dor - ființă, dor - jale" (3, p. 163) - toate aceste nuanțe, găsindu-și expresie prin ideea de ” dor nemărginit" (3, p. 163) În situaţia poetică descrisă se încearcă o anumită modalitate de comunicare ontologică, de subordonare față de tainele vieții și ale naturii,față de anumite legități de influență universală pentru a aprofunda certitudinea spațiului și timpului.

Lungu-i drumul codrului,

Dar mai lung al dorului;

Drumul codrului sfârșește,

A dorului se lungește;

Drumul codrului se gată

A dorului niciodată (13, p. 107).

În ipostaza de atribut uman de maximă generalitate, dorul transpare drept proiecție a unor dramatice confruntări și neliniști interioare, el exprimă o dorință nedefinită verbală, dar infinită ca lumea, ca universul teluric, își găsește expresie într-un grandios spectacol cosmic. Dorul de moarte este un reflex de 
sorginte mioritică, oferind o deschidere de orizont spre eternitate, de continuitate a vieții, dincolo de tărâmurile veșniciei, este "dorul stânei îndepărtate" (13, p. 138), aşa cum se exprimă D. Caracostea, în contemplarea lăuntrică a unui bilanț existențial. Bucuria și tristețea,amurgul și lumina,viața și moartea se condiționează reciproc și vibrează printr-o senzație de resemnare, de neliniște lăuntrică. Iar nostalgia trecerii se manifestă prin „melancolia nici prea grea, nici prea ușoară a unui suflet care suie și coboară pe un plan ondulat, indefinit...” (1, p. 85), sau „dorul unui suflet care vrea să treacă dealul ca obstacol al sorții și care totdeauna va mai avea de trecut încă un deal... sau duioșia unui suflet care circulă sub zodia unui destin ce-și are suișul și coborâșul, înălțările și cufundările de nivel monoton și fără sfârșit” (1, p. 222). În acest amalgam contradictoriu de gânduri și asociații, este accentuată ideea marii plecări, acele vămi tăinuite ale trecerii, pe care le parcurge „Marele Anonim” în drumul său spre eternitate.

Versul lui G. Vieru „Vestește-1, mamă, pe Dumnezeu/ Că am murit!” are tangență cu frământările sufletești ale omului din popor, în dramatica sa contemplare lăuntrică a lumii, survine din substraturile adânci ale doinirii populare. Starea de dor, identică cu „starea de doină”, amplifică viabilitatea geniului popular prin proiectarea unor incursiuni lirice de sorginte eminesciană, prin comunicarea ontologică în conformitate cu anumite resorturi general-umane.

\section{Referințe bibliografice:}

1 5AF ASM, 1963, ms.144, f.241-242, Hănăsenii - Noi - Leova, inf . Emilian Gonța, 53 ani, culeg. M. Savin.

2 AMZULESCU, Alexandru. Balade populare românești. București: Editura pentru Literatură, 1964.

3 BLAGA, Lucian. Trilogia culturii. București: E.P.L.U., 1969.

4 BUCUR, Marin, BLAGA, Lucian. Dor de eternitate. Cluj: Editura Dacia, 1971.

5 CARACOSTEA, Dumitru, BÂRLEA, Ovidiu. Problemele tipologiei folclorice. București: Editura Minerva, 1971.

6 CIMPOI, Mihai. Intoarcerea la izvoare. Chișinău: Literatura artistică, 1985.

7 COLAC, Tudor. La izvorul dorului. Folclor din Onițcani. Chișinău: Editura Grafema Libris, 2004.

8 COLAC, Tudor. La vatra doinelor. Festivalul doinei,. ediția I, Chișinău, Radio- Moldova, 2012. Chișinău: Editura Grafema Libris, 2013.

9 COLAC, Tudor. Nistrule, apleacă-ți malul... Folclor poetic din Transnistria. Chișinău: Editura Grafema Libris, 2004.

10 COTEANU, Ion. O dominantă a liricii populare: dorul. În: Stilistica funcțională a limbii române. București: E.D.P., 1973.

11 DRAGOMIR, Constantin. Cine-a zis dorului Dor...Din poezia populară de dragoste. Chișinău: Literatura artistică, 1989. 
12 DRĂGAN, Gheorghe. Poetica eminesciană: temeiuri folclorice. Iași: Editura Junimea, 1989.

13 JUNGHIETU, Efim. Cine-a zis doinu-doina...Doine și cântece lirice. Chișinău: Editura Literatura artistică, 1981.

Notă: Articolul a fost realizat în cadrul proiectului de cercetare 20.80009.1606.03 Contexte socio-culturale autohtone și interconexiuni europene în creația populară și literatura cultă din Basarabia (sec. XIX până în prezent), Institutul de Filologie Română „Bogdan Petriceicu-Hasdeu” al MECC. 